\title{
HOUSEHOLD FOOD DEMAND ANALYSIS: A SURVEY OF SEMI- URBAN AND RURAL HOUSEHOLDS IN SOUTH-WEST NIGERIA
}

\author{
B. T. OMONON, N. M. NKANG AND F. A. AJAO
}

(Received 3, July 2008; Revision Accepted 24, November 2008)

\section{ABSTRACT}

A two-stage Linear Approximate-Almost Ideal Demand Systems model was used to analyze household food demand in semi-urban and rural households in south-west Nigeria based on micro-level data from a multi-stage random sampling survey of one hundred and sixty two households. Aggregate food demand indicates inelastic sensitivity to price changes with the exception of grains. Individual food commodities, in the main, exhibit both price and income elastic behaviour. Expenditure elasticities ranged between 0.6670 and 18.2224 , were found to be generally higher than price elasticities. There was evidence of strong complementary relationships between individual food items. It is advocated that production of the set of price inelastic food items should be boosted, at least to a level where producers would not be forced to increase prices to the disadvantage of consumers. In like manner, increased supply of the highly price-elastic commodities would benefit both the consumer and the producer in that an accompanying reduction in prices with increased supply would lead to a higher margin of demand than the fall in price. Finally, it is suggested that food demand problems in the study area may be addressed more effectively via income rather than price policies, especially for luxuries such as meat/fish.

KEY WORDS: Household demand, elasticity, expenditure, food, LA-AIDS model.

\subsection{INTRODUCTION}

In the last few decades, food production in Nigeria has not kept pace with national food demand, probably due to low productivity in agriculture, high population growth, a reduction in real incomes of consumers as a result of inflation, in the midst of other factors. It, thus, follows that food security and/or food self-sufficiency is still a challenge in the country. And so, many individuals are constrained by both the economic and physical circumstances to consume less food than they need for healthy growth and proper functioning of their bodies.

One way of addressing this problem is by understanding the food demand structure of the economy and making use of it in government policy and/or intervention efforts geared at increasing food production in the country. This is necessary as demand elasticities are of considerable interest for policy purposes. Demand functions are used to evaluate the effects of changes in target prices on farmers' income, as well as, for forecasting by farmers, food processors and retailers, in an effort to plan their production and sales. Knowledge of households' food demand is an important step in solving the problem of food shortages through well articulated food and agricultural policies aimed at regulating supply. It is also useful in projecting the future food needs of the entire populace. Furthermore, estimation of income elasticities of demand for individual food items and total food is also a necessary activity for the development of food and nutritional policies, as the enhancement of income for both the consumer and producers through the use of effective policy instruments is a necessary step under economic development (Kenedal and Johnston, 1961; Abdulai et al, 1999).
In industrialised nations, the use of market demand for various foods is an important component in the formulation of agricultural as well as other public policies. However, in Nigeria, this has not been the regular practice because of poor planning data, as well as inadequate research which culminates in a dearth of useful information for policy making. In fact, previous studies on food demand in Nigeria are few and far between; most of which covered only one or two food groups without the others (for instance, Ojo, 1983; Adegeye, 1989, Are, 1992; Umoh, 1994; Igwe and Onyekwere, 2007). Apart from this, changes in the policy environment and household consumption patterns as a result of changes in socio-economic and demographic variables necessitate continuous research in this regard.

In view of the foregoing concerns, the current study analyses household demand for four major food groups as well as individual food items in the groups in Southwest Nigeria using the almost ideal demand systems based on the following research questions:

i. How do households allocate their income to the various food items?

ii. What is the nature of the own-price, cross-price as well as income elasticites of demand for the various food items?

iii. What are the effects of socio-economic and demographic variables on food consumption patterns of households?

Given that changes in food consumption patterns have great impact on food supply policy, the results of this endeavour would be of immense value to consumers, producers and government alike. Aside other remote benefits, the elasticities obtained from this study would show how much room the consumer has for reacting to changes in price; the producer would be able

B. T. Omonona, Department of Agricultural Economics, University of Ibadan, Ibadan, Oyo State, Nigeria

N. M. Nkang, Department of Agricultural Economics and Extension, University of Calabar, P. M. B. 1115, CalabarNigeria

F. A. Ajao, Department of Agricultural Economics, University of Ibadan, Ibadan, Oyo State, Nigeria 
to ascertain to what extent a price change on a certain item would affect his total revenue; while the results would indicate to government when to increase revenue through taxation on certain commodities.

The remainder of the paper is ordered as follows. Section two presents the analytical framework of this study. The next section discusses the estimated results while the last presents the policy implications and conclusions.

\subsection{METHODOLOGY \\ 2.1 The Model}

Utility theory postulates that the consumption pattern of any given household is a function of the household's preferences, income, prices faced by the household as well as certain biogenetic and demographic variables (age, sex, social class, etc). In the estimation of demand relationships, it is important to choose a model which takes all of the above-named variables into consideration. Furthermore, criteria such as, relative illustrative power, consistency with economic theory and simplicity of estimation are useful in choosing a demand model (Wang et al, 1996). Over time, several models have been developed and applied to the estimation of demand systems. However, Sadoulet and de Janvry (1995) chronicled three of them that have received substantial attention because of their relative empirical suitability. These include the Linear Expenditure Systems (LES) developed by Stone (1953), the Almost Ideal Demand Systems (AIDS) developed by Deaton and Muellbauer (1980) and the combination of these two systems into a Generalized Almost Ideal Demand Systems (GAIDS) proposed by Billino (1990). Another variant of the AIDS model is the Quadratic Almost Ideal Demand System (QUAIDS) derived by Banks et al (1997) and recently applied by Abdulai (2002). Empirical allusions to each of these specifications have been well reviewed in the literature on demand analysis (Wohlgenant 1984; Lee et al. 1994).

In this study, we make use of the AIDS model and specifically, the Linear Approximate Almost Ideal Demand System (LA-AIDS) model due to its popularity in demand analysis, flexibilty and the fact that the estimated coefficients in a LA-AIDS model are easy to interpret (Savadogo and Brandt, 1988; Abdulai, Jain and Sharma, 1999; Heien and Pompelli, 1988; Blanciforti and Green 1983; Heien and Wessells 1990; Lee et al, 1994; Fan et al, 1995; Jabarin 2005).

\subsection{Model Specification}

The budget share equation for the LA-AIDS model used in this study is given as:

$$
w_{i}=\alpha_{i}+\sum_{j=1}^{n} \gamma_{i j} \ln P_{j}+\beta_{i} \ln \left(\frac{x}{P_{s}}\right)
$$

Where:

$w_{i}=$ budget share of food item $i$

$\gamma_{i j}=$ slope coefficient associated with the $j^{\text {th }}$ food item in the $i^{\text {th }}$ share equation

$P_{j}=$ price of food item $j$

$P_{s}=$ Stone's price index, defined as: $\ln P_{s}=\sum_{i=1}^{n} w_{j} \ln P_{j}$

The use of the Stone price index makes the model linear in parameters $\alpha, \beta$ and $\gamma$, and thus the LA-AIDS model (Deaton and Muellbauer, 1980, Chalfant 1987; Cai et al 1998), and at the same time allows for the inclusion of demographic variables in the model through either scaling or translation methods (Sadoulet and de Janvry, 1995).

Demographic effects were incorporated in the model following Heien and Pompelli (1988) by allowing the intercept in equation (1) to be a function of demographic variables. Thus, the extended model including demographic variables and an error term is defined as:

$w_{i}=\alpha_{i}+\sum_{j=1}^{s} \alpha_{i j} d_{j}+\sum_{j=1}^{n} \gamma_{i j} \ln P_{i}+\beta_{i} \ln \left(\frac{x}{P_{s}}\right)+V_{i}$

Where:

$d_{j}$ is the $j^{\text {th }}$ demographic variable of which there are $s$ in number in equation (3).

$v_{i}$ is the error term

In order to ensure consistency with the demand theory, the theoretical properties of adding up, homogeneity in prices and income as well as Slustsky symmetry of cross effects of demand functions are subject to the following parametric restrictions:

Adding up,

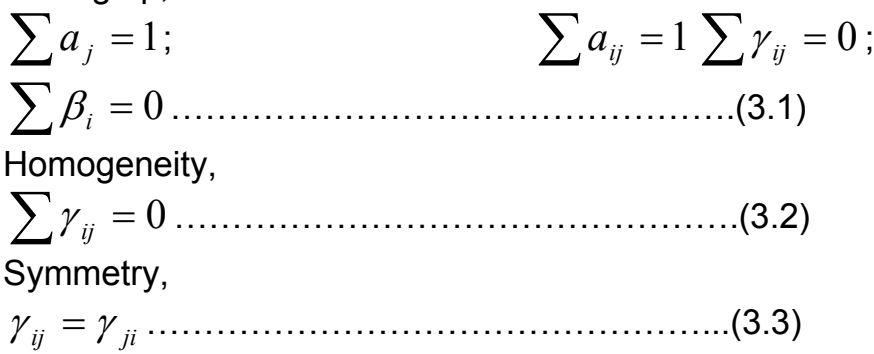

Based on the above formulations, we can derive the expenditure and price elasticities (Marshallian and Hicksian) in our LA-AIDS model.

The expenditure elasticities were derived as:

$e_{i}=\frac{\beta_{i}}{w_{i}}+1$

Accordingly, the uncompensated (Marshallian) price elasticities were computed as:

$\boldsymbol{e}_{i j}^{m}=\frac{\gamma_{i j}}{w_{i}}-\frac{\beta_{i}}{w_{i}} w_{j}-\delta_{i j}$

While the compensated Hicksian elasticities were derived from the Marshallian elasticity through the Slutsky equation following Chalfant (1987), as follows:

$\boldsymbol{e}_{i j}^{h}=\boldsymbol{e}_{i j}^{m}+w_{j} \cdot e_{i}$

Where:

$w_{j}$ is budget share of good $j$

$\delta_{i j}$ is the Kronecker delta, $\delta_{i j}=1$ for $i=j ; \delta_{i j}=0$ for $i \neq$ j

$e_{i j}^{h}$ represents Hicksian elasticity

$\boldsymbol{e}_{i j}^{m}$ represents Marshallian elasticity 
$e_{i}$ is the income elasticity for good $i$

In this study, the consumer expenditure allocation was represented in two stages. The first stage involved determining the allocation of consumer expenditure among different food groups namely, Grains, Roots/Tubers, Meat/Fish, and Vegetables/Fruits. In the second stage, expenditure on each of these food groups was allocated between individual food items within each of the main food groups. Allocation between food and non-food items was not determined because the aim of this study is primarily to estimate a separable demand system for food in the study area.

\subsection{The Data}

Micro-level data based on a survey of households was used in the analysis. The survey was carried out in Oyo State, about the largest in Southwest Nigeria. A multi-stage random sampling technique was used to select 162 households for data collection. Relevant data on households' socio-economic and demographic characteristics, income and expenditure on food items and information on food consumption as well as general information on food items were collected using structured questionnaire. Literate household heads were served with questionnaires to complete by themselves while non-literate household heads were interviewed by trained enumerators. Of the 162 households sampled for the study, only information from 152 households was used in the analysis because information in some of the questionnaires was incomplete.

The sampled households varied in age, education, monthly income levels as well as location. Mean age of households was 42.36, while the average number of years in school was 10.91. Moreover average monthly income for the sample was N24,574.1 while mean household size was 6 persons. Of the 152 respondents, 122 were urban dwellers while 30 lived in the rural areas. Again, there were 123 males and 29 females in the sample (Table $1 \mathrm{a}$ and1b). The selection of food items within each of the food groups is based on major foods consumed by Nigerian people, and in particular, those food consumed by the people of SouthWest Nigeria.

Table 1a: Some Characteristics of Surveyed Households

\begin{tabular}{|c|c|c|c|c|c|c|}
\hline & Age (years) & $\begin{array}{l}\text { Education } \\
\text { (Years of } \\
\text { Schooling) }\end{array}$ & $\begin{array}{l}\text { Monthly } \\
\text { (Naira) }\end{array}$ & Income & $\begin{array}{l}\text { Household } \\
\text { (Number) }\end{array}$ & Size \\
\hline Minimum & 21 & 0 & 2,000 & & 1 & \\
\hline Mean & 42.36 & 10.91 & $24,574.1$ & & 6 & \\
\hline Maximum & 74 & 20 & 90,000 & & 21 & \\
\hline S. Deviation & 11.57 & 5.99 & $16,135.9$ & & 2.88 & \\
\hline
\end{tabular}

Table 1b: Some Characteristics of Surveyed Households

\begin{tabular}{llll}
\hline Locality & & \multicolumn{2}{l}{ Gender of Household Heads } \\
\hline Urban & Rural & Male & Female \\
\hline $122(80.3 \%)$ & $30(19.7 \%)$ & $123(80.9 \%)$ & $29(19.1 \%)$ \\
\hline
\end{tabular}

\subsection{RESULTS AND DISCUSSION}

In this section we present the results as well as discussion of the derived elasticities based on the estimated budget share equations for both food groups and individual food items.

\subsection{Food Groups}

The first stage of the estimations provides the results of the budget share equations for the four food groups and they indicate that the included variables explain households' allocation of their budgets satisfactorily. The estimated adjusted coefficients of multiple determination are $0.8453,0.8018,0.7869$ and 0.6552 for vegetables/fruits, grains, roots/tubers, and meat/fish respectively (see Table 2 ). This implies that at least $65.52 \%$ of the variations in household expenditure allocation to the various food groups are captured by household income, prices and the included socio economic and demographic variables.

Particularly, age of household head shows a negative but significant effect on consumption of meat/fish, while income of households indicates a direct and significant influence on expenditure share of meat/fish. These results are informative and consistent with expectations. Furthermore, estimates show that sex was a significant predictor of household expenditure on meat/fish. The indication from the results is that femalehead households have a propensity to spend more on meat/fish than male-headed households (see, Hoddinott and Haddad, 1991). In the case of grains, the estimated coefficients of household size and income are positive and highly significant. This is also in line with theoretical underpinnings. Results for roots and tubers show that age is an important and significant variable that explains households' allocation of expenditure to tubers. The estimated budget share equation for vegetables and fruits shows that age, sex, and household size were not significant in explaining the proportion of households' income expended on the items.

Expenditure elasticity estimates (Table 3 ) for the four food groups are positive, indicating that all the food groups are normal goods. The elasticities vary considerably from 0.677 (grains) to 1.1759 (for meat/fish). The expenditure elasticity of vegetables/fruits though inelastic is very close to unity showing that consumers in the study area would increase their consumption of vegetables/fruits by approximately the same margin of increase in their incomes. For grains and roots/tubers, it implies that a $1 \%$ increase in income will result in a less than proportionate increase in their 
quantity demanded by consumers in the area (that is $0.677 \%$ and $0.882 \%$ respectively) while a $1 \%$ increase in income will result in a greater than proportionate $(1.176 \%)$ increase in thequantity demanded of meat/fish. These results imply that demand for meat/fish is income elastic, while the demand for other food groups is fairly income inelastic.

The own-price elasticities are negative for all food groups. This is consistent with economic theory, as the concavity constraint from utility theory requires that own-price Hicksian or Marshallian demand elasticities be negative.

The own-price elasticity (Hicksian) of grains (1.5426) is the highest, indicating that it is demand elastic. This implies that a $1 \%$ increase in grain price will cause quantity demanded of grains to decrease by $1.5426 \%$, ceteris paribus. This in turn will lead to a decrease in revenue for the producers. Therefore, if there is an increase in price of grains, households are compelled to re-adjust their pattern of demand by consuming less of it. Since it is one of the cheapest food items there is virtually no competitive product they can shift their demand to.

For the other food groups, the own-price elasticity is less than one, indicating that the demand is inelastic. Specifically, own-price elasticities for roots/tubers, vegetables/fruits and meat/fish are -0.1539 , -0.5901 , and -0.1788 respectively. This means that for a 1 percent increase in price of these food groups, there is a corresponding $0.1539 \%, 0.5901 \%$ and $0.1788 \%$ decrease in the expenditure shares of roots/tubers, vegetables/fruits, and meat/fish respectively. Inelastic demand implies that the consumer has little room for reaction. This is true for necessities and for goods that do not have close substitutes. For the producer, this means that a reduction in price of the commodity will cause a decline in total revenue while an increase in price will increase total revenue. The Hicksian crossprice elasticity reported, mostly indicate that the food groups are complements. However, there is substitution effect between meat/fish and price of roots/tubers $(0.2109)$. This value suggests that the opportunities for substitution between the two food groups are very low.

Table 2: Parameter Estimates for Food Groups

\begin{tabular}{|c|c|c|c|c|c|c|c|c|}
\hline $\begin{array}{l}\text { Explanatory } \\
\text { Variables }\end{array}$ & $\begin{array}{l}\text { Vegetabl } \\
\text { Fruits }\end{array}$ & es and & Meat anc & Fish & Grains & & $\begin{array}{l}\text { Roots } \\
\text { Tubers }\end{array}$ & and \\
\hline & Coeff. & t-value & Coeff. & t-value & Coeff. & t-value & Coeff. & t-value \\
\hline Constant & -0.1524 & -0.7163 & -0.2337 & -0.5465 & 2.4001 & $3.3985^{\star \star *}$ & 0.2948 & 0.6564 \\
\hline Age & -0.0002 & -1.4031 & -0.0006 & $2.3242^{* *}$ & -0.0002 & -0.5305 & 0.0005 & \\
\hline Gender & -0.0030 & -0.9356 & 0.0184 & $2.8958^{\star *}$ & -0.0040 & -09130 & $-\overline{0} 0049$ & -0.7315 \\
\hline Household Size & -0.0003 & -0.7902 & 0.0040 & 0.4890 & 0.0045 & $2.8746^{\star * *}$ & $\overline{-}-0008$ & -0.8160 \\
\hline $\begin{array}{l}\text { Household } \\
\text { Income }\end{array}$ & 0.0001 & $-2.0862^{* *}$ & 0.0001 & $2.0071^{* *}$ & 0.0000 & $4.3173^{* * *}$ & 0.0000 & 0.5096 \\
\hline $\begin{array}{l}\text { LnVegetables } \\
\text { price }\end{array}$ & 0.0271 & 0.5009 & -0.0262 & -0.2411 & -0.1655 & -0.9317 & $-\overline{0.1043}$ & -0.9146 \\
\hline $\begin{array}{l}\text { LnMeat \& Fish } \\
\text { price }\end{array}$ & -0.1053 & $2.7340^{* * *}$ & -0.1346 & $1.7397^{*}$ & -0.1248 & -0.9750 & $-\overline{0}$ & -0.3148 \\
\hline LnTuber price & 0.1297 & $2.1850^{\star *}$ & -0.1364 & -1.1433 & -0.6094 & $3.0506^{* * *}$ & 0.1687 & 1.3472 \\
\hline LnGrains price & 0.0817 & 1.4358 & -0.1398 & 1.2225 & -0.2668 & -1.4154 & $-\overline{0.1058}$ & -0.8806 \\
\hline $\mathrm{R}^{2}$ & 0.8691 & & 0.6613 & & 0.8255 & & 0.7913 & \\
\hline Adjusted $\mathrm{R}^{2}$ & 0.8453 & & 0.6552 & & 0.8018 & & 0.7869 & \\
\hline
\end{tabular}

$\left({ }^{* * *}\right),\left(^{* *}\right)$ and $\left({ }^{*}\right)$ denote significance at $1 \%, 5 \%$ and $10 \%$ levels respectively

Table 3: Marshallian, Hicksian and Expenditure Elasticities for Food Groups

\begin{tabular}{|c|c|c|c|c|c|c|c|}
\hline & Grain & Root/Tuber & Veg/Friut & Meat/Fish & $\begin{array}{l}\text { Own-price } \\
\text { Elasticities }\end{array}$ & $\begin{array}{l}\text { Expenditure } \\
\text { Elasticities }\end{array}$ & $\begin{array}{l}\text { Budget } \\
\text { Share }\end{array}$ \\
\hline \multicolumn{8}{|c|}{ Marshallian Elasticities } \\
\hline Grain & - & -1.8425 & -0.5032 & -0.3050 & -1.7514 & 0.6770 & 31.3 \\
\hline Root/Tuber & & -0.4388 & -0.3137 & -0.0449 & -0.4388 & 0.8820 & 32.3 \\
\hline Veg/Friut & & & -0.6648 & -1.3838 & -0.6648 & 0.9448 & 7.9 \\
\hline Meat/Fish & & & & -0.5198 & -0.5198 & 1.1759 & 29.0 \\
\hline \multicolumn{8}{|c|}{ Hicksian Elasticities } \\
\hline Grain & 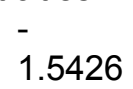 & -1.6238 & -0.4497 & -0.1086 & -1.5426 & & \\
\hline $\begin{array}{l}\text { Root/Tuber } \\
\text { Veg/Friut }\end{array}$ & & -0.1539 & $\begin{array}{l}-0.2440 \\
-0.5901\end{array}$ & $\begin{array}{l}0.2109 \\
-1.1098\end{array}$ & $\begin{array}{l}-0.1539 \\
-0.5901\end{array}$ & & \\
\hline Meat/Fish & & & & -0.1788 & -0.1788 & & \\
\hline
\end{tabular}




\subsection{Individual Food Items}

In the second stage of the estimations, the results of the factors that influence the expenditure share of specific food items within each group were obtained. The subsections that follow discuss these results as per the individual groups.

\subsubsection{Grains}

Three food items, namely, rice, maize and beans constituted the items under grains. The budget share equations estimated for these three items indicate that the included variables explained households' budget allocation on these items fairly well. Specifically, the adjusted coefficients of determination (shown in Table 4) were $0.6194,0.6195$ and 0.6190 respectively for rice, beans and maize. The effect of the included socioeconomic and demographic variables, though mixed, showed some similar influence on the three items. For instance, the results showed that household size, income and level of education of household head positively and significantly influenced expenditures on rice, beans and maize, while sex and age of household head were not significant predictors.

Interestingly, the computed expenditure elasticities (Table 5) for the three grain items are negative, that is -5.2837 (rice), -2.7532 (maize) and 1.0403 (beans), implying that they are inferior goods in the study area and that quantity demanded of these commodities will decrease with a substantial increase in income since households would be able to afford higherquality or preferred foods. Furthermore, estimated ownprice elasticities for the three food items were -3.8332 (rice), -1.0076 (maize) and -2.2814 (beans). They were elastic and carried the expected negative sign. These values imply that a $1 \%$ change in own-prices would lead to a greater than proportionate change in the quantity demanded of the items, in this case a reduction in quantity demanded. A plausible explanation for these results is the preference of consumers in the study area considering the fact that we are dealing with semi-urban and rural consumers who can easily turn to cheaper sources of energy as a result of increase in the prices of items like rice and maize. These results are informative in the sense that if producers in the study area increase the prices of rice or beans, total revenue will decrease, as the demand for these items will fall by a larger margin than the increase in price. The Hicksian cross price elasticities were in general, negative indicating complementarities between the food items.

Table 4: Parameter Estimates for Grains

\begin{tabular}{lllllll}
\hline Explanatory & \multicolumn{7}{c}{ Rice } & \multicolumn{5}{c}{ Beans } & Maize \\
\cline { 2 - 7 } Variables & Coeff. & $\mathrm{t}-\mathrm{value}$ & Coeff. & $\mathrm{t}$-value & Coeff. & $\mathrm{t}$-value \\
Constant & 1231.5400 & $2.3644^{* *}$ & 1225.3700 & $2.3538^{* *}$ & 1226.0500 & $2.3540^{* *}$ \\
Gender & 20.5565 & 1.4284 & 20.5503 & 1.4288 & 20.5525 & 1.4283 \\
Age & 0.1759 & 0.2877 & 0.1832 & 0.2999 & 0.1854 & 0.3039 \\
Education & 4.9900 & $2.6277^{* * *}$ & 4.9660 & $2.6164^{* * *}$ & 4.9505 & $2.6102^{* * *}$ \\
Household Size & 10.8661 & $5.2412^{* * *}$ & 10.8582 & $5.2402^{* * *}$ & 10.8535 & $5.2354^{* * *}$ \\
Household & 0.0016 & $3.8120^{* * *}$ & 0.0016 & $3.8145^{* * *}$ & 0.0016 & $3.8104^{* * *}$ \\
Income & & & & & & \\
LnRice Price & -225.1070 & -1.4137 & -222.5800 & -1.3983 & -222.4860 & -1.3970 \\
LnBeans Price & -152.6120 & -0.7234 & -42.8966 & -0.3915 & -42.9268 & -0.3916 \\
LnMaize Price & -42.1746 & -0.3847 & -151.7110 & -0.7195 & -152.3210 & -0.7220 \\
$\mathrm{R}^{2}$ & 0.6446 & & 0.6447 & & 0.6442 & \\
\hline Adjusted $\mathrm{R}^{2}$ & \multicolumn{7}{c}{0.6194} & 0.6195 & & 0.6190 & \\
\hline
\end{tabular}

Table 5: Marshallian, Hicksian and Expenditure Elasticities for Grains

\begin{tabular}{|c|c|c|c|c|c|c|}
\hline & Rice & Maize & Beans & $\begin{array}{l}\text { Own-price } \\
\text { Elasticities }\end{array}$ & $\begin{array}{l}\text { Expenditure } \\
\text { Elasticities }\end{array}$ & $\begin{array}{l}\text { Budget } \\
\text { Share }\end{array}$ \\
\hline \multicolumn{7}{|c|}{ Marshallian Elasticities } \\
\hline Rice & -0.7264 & 0.1180 & -1.0125 & -0.7264 & -5.2837 & 58.8 \\
\hline Maize & & -0.6965 & -5.2445 & -0.6965 & -2.7532 & 11.3 \\
\hline Beans & & & -1.9704 & -1.9704 & -1.0403 & 29.9 \\
\hline \multicolumn{7}{|c|}{ Hicksian Elasticities } \\
\hline Rice & -3.8332 & -0.4790 & -2.5923 & -3.8332 & & \\
\hline Maize & & -1.0076 & -6.0677 & -1.0076 & & \\
\hline Beans & & & -2.2814 & -2.2814 & & \\
\hline
\end{tabular}

\subsubsection{Roots and Tubers}

The roots/tubers food group is comprised of yam, gari, Yam flour and cassava flour. The estimated budget share equations for the respective items show that the included variables explained the variations in expenditure for the respective items almost $100 \%$, though at various extents. This deduction is based on an estimated adjusted coefficient of multiple determination of 0.9999 for all the individual food items in the food group (Table 6). In all the four food items, household size was a significant and positive predictor of household's budget share in those items, while income was also significant in all others except cassava flour. Again, gender was significant in explaining expenditures on yam and yam flour but not in the case of gari and cassava flour. It is however important to note that age and education were significant in explaining expenditures on yam flour only but were not in all other cases. 
Presented in Table 7 below is a summary of the computed elasticities of the food items making up roots and tubers food group. The compensated own-price elasticities for the four food items, -0.6374 (yam), 4.7238 (gari), -2.8530 (yam flour) and -0.3255 (cassava flour) are negative and in tune with theoretical expectations. All of them are elastic except those of yam and cassava flour. This implies that an increase in the prices of gari and yam flour would reduce the quantity of the items that would be bought by a larger proportion than the price increase, while the reverse would apply in the case of yam and cassava flour, since their demand is inelastic. These results suggest that if the producers increase the price of these food items, except those of yam and cassava flour, total revenue of producers will decrease because quantity demand will fall, however, if price of yam and cassava flour increase, total revenue of producers will increase.

The Hicksian cross-price elasticities of demand are both negative and positive, implying complementarily in some cases and substitution in others. Specifically, substitution effects are found between yam and cassava flour (1.2410), gari and cassava flour (2.1923), and yam flour and cassava flour (1.1059). The estimated expenditure elasticities for the food items range from 4.1034 for yam to 6.3303 for gari, indicating that they are all normal goods and are all income elastic. Thus, increase in income will cause an increase in expenditure on all the four items.

Table 6: Parameter Estimates for Roots and Tubers

\begin{tabular}{|c|c|c|c|c|c|c|c|c|}
\hline Explanatory & Yam & & Gari & & Yam Fl & & Cassava & Flour \\
\hline Variables & Coeff. & t-value & Coeff. & t-value & Coeff. & t-value & Coeff. & t-value \\
\hline Constant & 5.1140 & $2.6241^{* \star *}$ & 7.4035 & 4.7030 & 7.0044 & $3.7052^{* \star *}$ & 6.8322 & $3.2608^{* * *}$ \\
\hline Gender & 0.1650 & $2.8014^{* * *}$ & 0.0763 & 1.6060 & 0.1191 & $2.0876^{\star *}$ & 0.03158 & 0.4997 \\
\hline Age & 0.0013 & & - & -1.4433 & - & $-2.0293^{* *}$ & 0.0040 & 1.6038 \\
\hline & & 0.5797 & 0.0027 & & 0.0046 & & & \\
\hline Education & 0.0117 & 0.7316 & 0.0004 & 0.0310 & 0.0707 & $4.5561^{* \star *}$ & -0.0013 & -0.0763 \\
\hline Household Size & 0.0223 & $2.6980^{* * *}$ & 0.0392 & $5.8808^{* * *}$ & 0.0255 & $3.1830^{* * *}$ & 0.0315 & $3.5477^{* * *}$ \\
\hline $\begin{array}{l}\text { Household } \\
\text { Income }\end{array}$ & 0.0000 & $3.8234^{* * *}$ & 0.0000 & $3.1143^{* * *}$ & 0.0000 & $6.5724^{* * *}$ & 0.0000 & 1.0808 \\
\hline LnYam Price & 0.0128 & 0.0242 & 0.2080 & -0.4865 & $-\overline{0}-6021$ & -1.1724 & -0.3762 & -0.6611 \\
\hline LnGari Price & $\begin{array}{l}- \\
1.2921\end{array}$ & $\overline{3}-2260^{\star * *}$ & $\overline{-}-7354$ & $\overline{2.2732^{\star *}}$ & $\overline{-}$ & $\overline{3} .4471^{\star * *}$ & -0.4981 & -1.1561 \\
\hline LnYamFlour Price & 0.8241 & $\begin{array}{c}- \\
1.1658\end{array}$ & -2.2934 & $4.0166^{\star * *}$ & -1.1767 & $-1.7161^{*}$ & -1.9954 & $-\overline{2.6257^{\star * *}}$ \\
\hline $\begin{array}{l}\text { LnCassavaFlour } \\
\text { Price }\end{array}$ & 0.3340 & 0.5296 & 0.3732 & 0.7327 & 0.2535 & 0.4194 & 0.2315 & 0.3415 \\
\hline $\mathrm{R}^{2}$ & 0.9999 & & 0.9999 & & 0.9999 & & 0.9999 & \\
\hline Adjusted $\mathrm{R}^{2}$ & 0.9999 & & 0.9999 & & 0.9999 & & 0.9999 & \\
\hline
\end{tabular}

Table 7: Marshallian, Hicksian and Expenditure Elasticities for Roots and Tubers

\begin{tabular}{|c|c|c|c|c|c|c|c|}
\hline & Yam & Gari & Yam Flour & $\begin{array}{l}\text { Cassava } \\
\text { Flour }\end{array}$ & $\begin{array}{l}\text { Own-price } \\
\text { Elasticities }\end{array}$ & $\begin{array}{l}\text { Expenditure } \\
\text { Elasticities }\end{array}$ & $\begin{array}{l}\text { Budget } \\
\text { Share }\end{array}$ \\
\hline \multicolumn{8}{|c|}{ Marshallian Elasticities } \\
\hline Yam & $\begin{array}{l}- \\
1.9628\end{array}$ & -4.5838 & -3.4265 & 0.39167 & -1.9628 & 4.1034 & 32.3 \\
\hline Gari & & -5.9139 & -13.7029 & 0.8819 & -5.9139 & 6.3303 & 18.8 \\
\hline Y/Flour & & & -4.1369 & 0.1635 & -4.1369 & 4.5528 & 28.2 \\
\hline \multicolumn{8}{|c|}{ Hicksian Elasticities } \\
\hline Yam & $\begin{array}{l}- \\
0.6374\end{array}$ & -3.8123 & -2.2693 & 1.2410 & -0.6374 & & \\
\hline Gari & & -4.7238 & -11.9177 & 2.1923 & -4.7238 & & \\
\hline Y/Flour & & & -2.8530 & 1.1059 & -2.8530 & & \\
\hline C/Flour & & & & -0.3255 & -0.3255 & & \\
\hline
\end{tabular}

\subsubsection{Meat and Fish}

The meat and fish food group covered beef, fish, chicken and gelatin or ponmo. Just like in the case of the roots and tuber food group, the estimated budget share equations for the respective items show that the included variables explained the variations in expenditure for the respective items almost $100 \%$, though at various degrees based on an adjusted $R^{2}$ value of 0.9999 for each of the individual items (see
Table 8). For all the budget share equations in this group, household size and income were significant in explaining the changes in household expenditure on those items. However, while, household size was negative in all cases, income was positive in three cases but negative in the case of ponmo. Furthermore, the gender variable was significant but negative in all the cases except chicken. Moreover, age was significant and positive in two cases (chicken and ponmo), while 
education was only significant in the case of ponmo, but with a negative sign.

The elasticity estimates for the four food items are presented in the Table 9. The own-price elasticities for all items, -2.7121 (beef), -2.2998 (fish), -4.0345 (chicken) and -0.3924 (ponmo) are negative, which conform to a priori expectations. These results indicate that all items except ponmo are price-elastic, meaning that ponmo is price-inelastic. Therefore increase in the price of ponmo will not cause a fall in the demand for it, but increase in the prices of the other three (beef, fish and chicken) will give rise to a decline in the quantity demand by households in the study area.
The cross-price elasticities for most of the items are negative, indicating that they are mostly complements. However, there are important cases of substitution between the items. For example, there is substitution effect in the case of Beef and fish (1.1710), Beef and ponmo (1.3226), Fish and ponmo (2.4632), and chicken and ponmo (5.7731).

The expenditure elasticities are all positive as expected, indicating that beef, fish, chicken and ponmo are normal goods in the study area. The values range from 2.2225 for ponmo to 18.2240 for chicken, meaning that the four food items are expenditure elastic and that when income rises, demand for these goods also rises

Table 8: Parameter Estimates for Meat and Fish

\begin{tabular}{|c|c|c|c|c|c|c|c|c|}
\hline Explanatory & Beef & & Chicken & & Ponmo & & Fish & \\
\hline Variables & Coeff. & t-value & Coeff. & t-value & Coeff. & t-value & Coeff. & t-value \\
\hline Constant & -1.0780 & -0.2291 & -4.8462 & -0.9912 & -1.9924 & -0.3952 & -3.829 & -0.6565 \\
\hline Gender & -0.1681 & $-1.7192^{*}$ & 0.1021 & $1.0051^{*}$ & -0.1890 & $-1.8043^{*}$ & -0.322 & $\overline{-}^{2.6364^{* \star *}}$ \\
\hline Age & 0.0037 & 1.3437 & 0.0078 & $1.7733^{*}$ & -0.0103 & $2.2742^{* *}$ & 0.0068 & 1.2998 \\
\hline Education & -0.0236 & -0.8292 & -0.0251 & -0.8486 & -0.0516 & $-1.6924^{*}$ & -0.054 & -1.5369 \\
\hline Household Size & -0.0621 & $-4.3865^{\star \star \star}$ & -0.0566 & $-\overline{3.8507^{\star * *}}$ & -0.0609 & $-4.0205^{\star * *}$ & $\overline{-}-0526$ & $-11114^{\star * *}$ \\
\hline Household Income & 0.0000 & $5.4248^{\star * *}$ & 0.000 & $5.9713^{* * *}$ & -0.0000 & $-6.2519^{* * *}$ & 0.000 & $6.1489^{* * *}$ \\
\hline LnBeef Price & -1.4085 & -1.3880 & -1.0694 & -1.0142 & -0.3417 & -0.3142 & 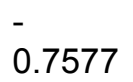 & -0.6148 \\
\hline LnFish Price & 0.3233 & 0.3316 & -0.1447 & -0.1428 & -0.6465 & -0.6190 & 0.6947 & -0.5749 \\
\hline LnChicken Price & -0.9244 & $-1.6914^{*}$ & -0.4113 & -0.7244 & -1.0984 & $-1.8759^{*}$ & $\overline{-}-7730$ & -1.1142 \\
\hline $\begin{array}{l}\mathrm{Ln} \text { Ponmo Price } \\
\mathrm{R}^{2}\end{array}$ & $\begin{array}{l}0.3392 \\
0.9999 \\
\end{array}$ & 0.3247 & $\begin{array}{l}0.9534 \\
0.9999 \\
\end{array}$ & 0.8784 & $\begin{array}{l}0.1888 \\
0.9999 \\
\end{array}$ & 0.1687 & $\begin{array}{l}0.7610 \\
0.9999 \\
\end{array}$ & 0.5877 \\
\hline Adjusted $\mathrm{R}^{2}$ & 0.9999 & & 0.9999 & & 0.9999 & & 0.9999 & \\
\hline
\end{tabular}

Table 9: Marshallian, Hicksian and Expenditure Elasticities for Meat and Fish

\begin{tabular}{|c|c|c|c|c|c|c|c|}
\hline & Beef & Fish & Chicken & Ponmo & $\begin{array}{l}\text { Own-price } \\
\text { Elasticities }\end{array}$ & $\begin{array}{l}\text { Expenditure } \\
\text { Elasticities }\end{array}$ & $\begin{array}{l}\text { Budget } \\
\text { Share }\end{array}$ \\
\hline \multicolumn{8}{|c|}{ Marshallian Elasticities } \\
\hline Beef & - & -0.1479 & -2.1847 & 0.5611 & -4.1574 & 3.2406 & 44.6 \\
\hline Fish & & -3.7062 & -2.0240 & 1.6512 & -3.7062 & 3.4555 & 40.7 \\
\hline Chicken & & & -5.0915 & 1.4905 & -5.0915 & 18.2240 & 5.8 \\
\hline Ponmo & & & & -0.1299 & -0.1299 & 2.2225 & 8.9 \\
\hline \multicolumn{8}{|c|}{ Hicksian Elasticities } \\
\hline Beef & $\begin{array}{l}- \\
2.7121\end{array}$ & 1.1710 & -1.9967 & 1.3226 & -2.7121 & & \\
\hline Fish & & -2.2998 & -1.8238 & 2.4632 & -2.2998 & & \\
\hline Chicken & & & -4.0345 & 5.7731 & -4.0345 & & \\
\hline Ponmo & & & & -0.3924 & -0.3924 & & \\
\hline
\end{tabular}

\subsubsection{Vegetables and Fruits}

The food items under Vegetables and Fruits are green leaves, okra, banana and plantains. The budget share equations for these items (shown in Table 10) indicate that the included variables in the respective equations explain households' expenditure on these items satisfactorily. Particularly, the adjusted coefficients of determination were $0.7780,0.7629,0.7489$ and 0.6425 , in that order, for Green Leaves, Okra, Banana and Plantain. The effects of the included variables were generally mixed. Household income was a significant predictor of household expenditure on Green Leaves and Banana, whereas it was not significant in the case of okra and plantains. Similarly, while, Locality significantly influenced expenditure on Okra and Bananas, it did not matter for Green leaves and Plantain. Age and educational level of household head explained household expenditure on Green Leaves significantly but household size was only significant in explaining household expenditure allocation on Okra and Plantains.

Table 11 shows the estimated elasticities for the four food items in this food group. Own-price elasticities for the four items, -0.4909 (Green Leaves), -2.4997 
(okra), -46153 (Banana) and -4.6863 (Plantain) are negative, as expected. These results imply that Green leaves is the only demand inelastic food item. Therefore, if prices of okra, banana and plantain increase, demand for the items will fall thereby decreasing the total revenue of the producers of these food items. Since green leaves have inelastic demand, increase in price will not cause a fall in its demand. This is likely since Green leaves have no close substitutes in the study area, as they are mostly used for soups and stews.

The cross-price effects are mostly those of substitution, and just one complementary relationship. The most significant relationships are the ones between
Green Leaves and Okra (0.0752) which is substitution and that between Banana and Plantain (-0.7637) which is complementary.

The expenditure elasticities for Okra and Green leaves are positive, indicating that they are normal goods and their consumption will increase with increase in income. Moreover their values are greater than one, indicating that their demand is income-elastic. However, Banana and Plantain have negative expenditure elasticities indicating that they are inferior goods, and that their consumption will decrease with an increase in income.

Table 10: Parameter Estimates for Vegetables and Fruits

\begin{tabular}{|c|c|c|c|c|c|c|c|c|}
\hline \multirow[t]{2}{*}{$\begin{array}{l}\text { Explanatory } \\
\text { Variables }\end{array}$} & \multicolumn{2}{|c|}{ Green Leaves } & \multicolumn{2}{|l|}{ Okra } & \multicolumn{2}{|l|}{ Banana } & \multicolumn{2}{|l|}{ Plantain } \\
\hline & Coeff. & t-value & Coeff. & t-value & Coeff. & $\mathrm{t}$-value & Coeff. & t-value \\
\hline Constant & 1.9766 & 0.7123 & 0.0387 & 0.0211 & 462.9450 & 0.9674 & 1189.5600 & $2.3442^{* *}$ \\
\hline Locality & 0.0905 & 1.4111 & 0.0824 & $1.947^{*}$ & 19.1623 & $1.7481^{*}$ & 17.5726 & 1.4514 \\
\hline Gender & $\overline{-} 0.0670$ & 1.4011 & $\overline{-} 0.0516$ & -1.6346 & 6.2002 & 0.7193 & - & - \\
\hline Age & 0.0035 & $1.7206^{*}$ & $\overline{-} .0004$ & -0.2930 & - & - & 0.3773 & 1.0378 \\
\hline Education & 0.0151 & $3.0648^{* * *}$ & 0.0032 & -0.9802 & - & - & - & - \\
\hline Household Size & 0.0035 & 0.4753 & 0.0176 & $3.6241^{* * *}$ & 1.0916 & 0.8956 & 3.6661 & $2.7782^{* * *}$ \\
\hline $\begin{array}{l}\text { Household } \\
\text { Income }\end{array}$ & 0.0000 & $2.6351^{* * *}$ & 0.0000 & -0.5321 & 0.0004 & $1.6664^{*}$ & 0.0001 & 0.2694 \\
\hline LnOkra Price & 0.2590 & 0.5774 & $-\overline{0.2286}$ & -0.7716 & 19.0486 & 0.2374 & -65.2198 & -0.7659 \\
\hline $\begin{array}{l}\text { LnG/Leaves } \\
\text { Price }\end{array}$ & 0.0515 & 0.1705 & 0.0437 & -0.2191 & 11.2676 & 0.2080 & -104.6860 & $-1.8264^{*}$ \\
\hline LnBanana Price & 0.0995 & 0.1002 & 0.0655 & -0.0999 & 69.5645 & 0.3918 & 8.3599 & 0.0448 \\
\hline $\begin{array}{l}\text { LnPlantain Price } \\
\mathrm{R}^{2}\end{array}$ & $\begin{array}{l}1.1589 \\
0.8379\end{array}$ & 1.2639 & $\begin{array}{l}0.5690 \\
0.81146\end{array}$ & 0.9399 & $\begin{array}{l}91.9557 \\
0.7995\end{array}$ & 0.5797 & $\begin{array}{l}-131.6570 \\
0.6662\end{array}$ & -0.7869 \\
\hline Adjusted $\mathrm{R}^{2}$ & 0.7780 & & 0.7629 & & 0.7489 & & 0.6425 & \\
\hline
\end{tabular}

Table 11: Marshallian, Hicksian and Expenditure Elasticities for Vegetables and Fruits

\begin{tabular}{|c|c|c|c|c|c|c|c|}
\hline & $\begin{array}{l}\text { Green } \\
\text { Leaves }\end{array}$ & Okra & Banana & Plantain & $\begin{array}{l}\text { Own-price } \\
\text { Elasticities }\end{array}$ & $\begin{array}{l}\text { Expenditure } \\
\text { Elasticities }\end{array}$ & $\begin{array}{l}\text { Budget } \\
\text { Share }\end{array}$ \\
\hline \multicolumn{8}{|c|}{ Marshallian Elasticities } \\
\hline $\begin{array}{l}\text { Green } \\
\text { Leaves }\end{array}$ & -0.9021 & -0.0637 & 0.0237 & 0.2371 & -0.9021 & 1.0281 & 40.3 \\
\hline Okra & & -2.6485 & 0.0475 & 0.0280 & -2.6485 & 1.0772 & 13.9 \\
\hline Banana & & & -3.9895 & 0.4839 & -3.9895 & -4.1448 & 15.4 \\
\hline Plantain & & & & -4.2921 & -4.2921 & -1.3096 & 30.4 \\
\hline \multicolumn{8}{|c|}{ Hicksian Elasticities } \\
\hline Green & -0.4909 & 0.0752 & 0.1789 & 0.5465 & -0.4909 & & \\
\hline Leaves & & & & & & & \\
\hline $\begin{array}{l}\text { Okra } \\
\text { Banana }\end{array}$ & & -2.4997 & $\begin{array}{l}0.2101 \\
-4.6153\end{array}$ & $\begin{array}{l}0.3522 \\
-0.7637\end{array}$ & $\begin{array}{l}-2.4997 \\
-46153\end{array}$ & & \\
\hline Plantain & & & & -4.6863 & -4.6863 & & \\
\hline
\end{tabular}




\subsection{CONCLUSIONS AND POLICY IMPLICATIONS}

The present study shows that aggregate food demand in the study area is inelastic to price changes with the exception of grains. Aggregate expenditure elasticities also reveal that Meat/Fish are luxury foods while the others are necessities. Results further show that there were no significant price effects on the budget share equations for the food groups, except for price of meat/fish on expenditure on vegetables/fruits, and price of roots/tubers, on expenditure on grains. The most significant socio-economic variables were household size and household income. However, gender and age of household heads were also significant in explaining the expenditure on meat/fish. Interestingly, no variable was significant in explaining the expenditure on roots/tubers at both 1 and 5 percent levels of significance.

Individual food commodities were found to be generally price and income elastic. With the exception of yam, cassava flour, Ponmo and Green leaves which were price-inelastic, all other food items were priceelastic. Rice, maize, beans, banana and plantain were found to be inferior foods in the study area, with negative expenditure elasticities, while the others were normal/luxury foods, exhibiting positive/relatively high expenditure elasticities of demand. It was found that expenditure elasticities were in general higher than price elasticities. Remarkably, Chicken had the highest expenditure elasticity of demand with a value of 18.2224. Cross-price elasticities were in the main found to be negative, indicating strong complementarities between the individual food items. However, there were meaningful substitution effects observed among Roots/Tubers and Meat/Fish, as well.

The findings above are not without implications. We begin with the inelastic own-price elasticities of individual food items. Since the own-price elasticities of yam, cassava flour, Ponmo and Green leaves are less than unity (in absolute terms), producers could benefit from increased prices since the consumers would react by a less than proportionate margin if their prices were increased. On the other hand, for rice, maize, beans, gari, yam flour, beef, fish, chicken, okra, Banana, and Plantain that have shown elastic price behaviours, lower prices would benefit the producer since consumers would react by a larger than proportionate margin in terms of the price reduction. It is recommended that government should boost the production of the set of price inelastic food items at least to a level where producers would not be forced to increase prices to the disadvantage of consumers. In the same manner, since consumers stand a chance of greatly reducing their consumption of the highly price elastic food items, notably meat/fish products, which their bodies seriously need, a good solution is to help producers increase supply such that reduced prices would benefit both the consumer and the producer at the end of the day.

The implication of higher income elasticities compared with price elasticities is that food demand problems in the study area may be addressed more effectively via income policies than price policies. So, enhancing the income of consumers in the study area would increase purchasing power and hence demand for normal/luxury food items. Specifically, the exceptionally high income elasticity for Chicken has far reaching implications. First, it suggests that the demand for Chicken will continue to increase as household income increases, albeit at a much higher margin than the margin of rise in incomes. Secondly, going by the high income elasticity for Chicken, a need for increased Chicken production arises to keep pace with the demand that would arise from increased incomes if prices were to be kept at the same level. To achieve this, there has to be concerted effort to increase the production of maize which is the major ingredient in poultry feed compounding, as well as increase the proportion of maize output that goes into poultry production given that there is overbearing demand for direct household consumption and other agro-industrial processing in the country.

\section{REFERENCES}

Abdulai, A., 2002. Household demand for food in Switzerland: a quadratic almost ideal demand system. Swiss Journal of Economics and Statistics, 138: 1-18

Abdulai, A., Jain, K. D., Sharma, K. A., 1999. Household food demand analysis in India. Agric Econ. 50, 316-327.

Adegeye, A., 1989. A statistical analysis of demand for beef in the Western States of Nigeria.Readings in Agricultural Marketing, University of Ibadan, Nigeria.

Are, W. A., 1992. Food consumption patterns: a case study of Ibadan, Oyo State. B.Sc. Thesis, Department of Agricultural Economics, University of Ibadan, Nigeria.

Billino, C., 1990. A generalised version of the almost ideal and translog demand systems. Econ. Letters. 34, 127-129.

Blanciforti, L. and Green, R., 1983. An almost ideal demand system incorporating habits: an analysis of expenditures on food and aggregate community groups. Rev. Econ \& Stat. 65, 511515.

Cai, H., Brown, C., Wan, G. and Longworth, J., 1998. Income strata and meat demand in urban China. Aus. Agribusiness Rev. 6: 100-120.

Chalfant, J. A., 1987. A globally flexible, almost ideal demand system. J. Bus. \& Econ. Stat. 5, $233-$ 242.

Deaton, A., Muellbauer, J., 1980. An almost ideal demand system. Am. Econ. Rev. 70, 312-326.

Fan, S., Wailes, E. and Cramer, G., 1995. Household demand in rural China: A Two-stage LES-AIDS Model. Am. J. Agric. Econ. 77: 54-62.

Heien, D. and Pompelli, G., 1988. The demand for beef products: Cross-sectional estimation of 
demographic and economic effects. West J. Agric. Econ. 13, 37 - 44.

Heien, D. and Wessells, C., 1990. Demand systems estimation with micro-data: A censored regression approach. J. Bus. Econ. Stat. 8: 365371.

Hoddinott, J. and Haddad, L. J., 1991. Household expenditures, child anthropometric status and Intra-household division of income: Evidence from Cote d'Ivoire. International Food Policy Research Institute, Washington, D. C. Mimeographed Paper

Igwe, K. C. and Onyekwere, O. N., 2007. Meat demand analysis in Umuahia metropolis, Abia State, Nigeria. Agric. J. 2: 550-554.

Jabarin, A., 2005. Estimation of meat demand system in Jordan: An almost ideal demand system. Int. J. Consumer Studies, 29: 232-238.

Kenedal, H. and Johnston, B. F., 1961. Urban food expenditure patterns in Tropical Africa. Food Research Institute Studies. 11: 229-75.

Lee, J. Y., Brown, M. G. and Seale J. L., 1994. Model choice in consumer analysis: Taiwan, 1970 - 89. Am. J. Agric. Econ. 76: 504-512

Ojo, A. W., 1983. An analysis of consumption expenditure patterns in urban cities: A case
Study of Ibadan City. B.Sc. Thesis, Department of Agricultural Economics, University of Ibadan, Nigeria.

Sadoulet, E., de Janvry, A., 1995. Quantitative Development Policy Analysis. The John Hopkins University Press. Baltimore.

Stone, R., 1953. The measurement of consumers' expenditure and behavior in the United Kingdom, 1920-1938. Cambridge University Press, Cambridge.

Savadogo, K. and Brandt, J. A., 1988. Household food demand in Burkina Faso: implications for food policy. Agric. Econ. 2: 345-364.

Umoh, G. S., 1994. Household food consumption and income distribution pattern in Nigeria: a case study of Uyo metropolis. M.Sc. Thesis, Department of Agricultural Economics, University of Ibadan, Nigeria.

Wang, H., Halbrendt, C. and Johnson, S., 1996. A nontested test of AIDS vs. the translog demand system. Econ. Letters. 51: 139-143.

Wohlgenant, M. K., 1984. Conceptual and functional form issues in estimating demand elasticities, Am. J. Agric. Econ. 66: 211-217 